Kansas State University Libraries

New Prairie Press

Conference on Applied Statistics in Agriculture

2005 - 17th Annual Conference Proceedings

\title{
EVALUATING CLINICAL MASTITIS IN DAIRY CATTLE FED MONENSIN
}

Meihua Qiao

Daniel Mowrey

Alan Zimmermann

James T. Symanowski

Howard B. Green

See next page for additional authors

Follow this and additional works at: https://newprairiepress.org/agstatconference

Part of the Agriculture Commons, and the Applied Statistics Commons

\section{(c) (1) $\Theta \Theta$}

This work is licensed under a Creative Commons Attribution-Noncommercial-No Derivative Works 4.0 License.

\section{Recommended Citation}

Qiao, Meihua; Mowrey, Daniel; Zimmermann, Alan; Symanowski, James T.; Green, Howard B.; and Wilkinson, John I. D. (2005). "EVALUATING CLINICAL MASTITIS IN DAIRY CATTLE FED MONENSIN," Conference on Applied Statistics in Agriculture. https://doi.org/10.4148/2475-7772.1137

This is brought to you for free and open access by the Conferences at New Prairie Press. It has been accepted for inclusion in Conference on Applied Statistics in Agriculture by an authorized administrator of New Prairie Press. For more information, please contact cads@k-state.edu. 


\section{Author Information}

Meihua Qiao, Daniel Mowrey, Alan Zimmermann, James T. Symanowski, Howard B. Green, and John I. D. Wilkinson 


\title{
EVALUATING CLINICAL MASTITIS IN DAIRY CATTLE FED MONENSIN
}

\author{
Meihua Qiao ${ }^{1}$, Daniel Mowrey ${ }^{1}$, Alan Zimmermann ${ }^{1}$, James Symanowski ${ }^{1}$, \\ Howard Green $^{2}$, and John Wilkinson ${ }^{2}$ \\ ${ }^{1}$ Global Statistics and Information Sciences, Eli Lilly and Company, Indianapolis, IN 46225 \\ 2 Elanco Animal Health, Eli Lilly and Company, Greenfield, IN 46140
}

\begin{abstract}
The effect of Monensin on clinical mastitis in dairy cattle was evaluated from data collected at nine geographical clinical field trials using 966 Holstein cows and heifers in the United States and Canada. At each site, a randomized complete block design was conducted. Monensin (Rumensin ${ }^{\circledR}$ ) was fed at concentrations of $0,8,16$, or 24 ppm in a total mixed ration beginning 21 days before first calving for all nine sites, up to 7 days after second calving for six sites, and 203 days after second calving for three sites. Quarter milk samples were taken and cultured to determine the causative pathogen for each mastitis case and if clinical signs were observed the disease data were grouped according to etiology and analyses conducted. Analyses were conducted for all clinical mastitis cases as well as for a breakdown of the clinical mastitis cases into microorganism group levels.
\end{abstract}

A generalized linear mixed model and a linear mixed model were used to determine if there were significant differences in clinical mastitis between the non-zero concentrations of Monensin and controls. Response variables for the clinical mastitis cases that were analyzed using a generalized linear mixed model were Animal rate, Quarter rate, Observation rate, and Incident rate. An additional response variable, Average case duration, was analyzed using a linear mixed model. Inferences from the analyses indicate that Monensin does not influence the susceptibility of dairy cattle to clinical mastitis.

Key words: Monensin, Rumensin, Clinical Mastitis, Generalized Linear Mixed Model, Linear Mixed Model, Dairy Cattle.

\section{INTRODUCTION}

Mastitis is generally recognized as a very costly disease to the dairy industry. It manifests itself in lowered milk yield, increased costs of production, and reduced milk quality. Annually, economic loss due to mastitis in the United States is estimated to be $\$ 185$ per cow. If the cost per cow is multiplied by the total number of milk cows ( 9.5 million head), the total annual loss of mastitis is about $\$ 1.8$ billion. Therefore, it is critical to determine the impact of any new technology on mastitis. 
Monensin has been fed to beef cattle in United States and twenty other countries for over twenty five years for the control of coccidiosis and the enhancement of growth performance.

Studies were conducted to determine the effect of Monensin on milk production efficiency, health and safety in dairy cattle. Nine clinical field trials were conducted in the United States and Canada which involved 966 Holstein cows and heifers. Efficacy data as well as health and safety data were collected for each cow and pooled for analysis. Clinical mastitis data were analyzed to determine if Monensin had any impact on the susceptibility of dairy cattle to clinical mastitis.

\section{MATERIALS AND METHODS}

Monensin was fed to dairy cattle at concentrations of $0,8,16$, or $24 \mathrm{ppm}$ in a total mixed ration (dry matter basis) at all nine sites, beginning approximately 21 days before anticipated calving (Calving 1) and continuing through the following lactation and dry period, until seven days after the next calving (Calving 2). Feeding of Monensin continued in three of the nine sites until approximately 203 days in milk of the second lactation. Of the 966 Holstein cows and heifers that started the study, only 372 were designated to continue in the three trial sites. Of the 372 animals, two hundred forty nine began the second lactation.

\section{DATA COLLECTION AND SUMMARIZATION}

Cows were checked for clinical signs of mastitis at each milking. Quarter milk samples were collected if clinical signs were observed. Quarter milk samples collected were cultured to determine the causative pathogen if mastitis was detected, then the pathogen was classified according to etiology, Table 1, before being analyzed. Individual incidents (cases) and the days over which incidents persisted were recorded for each quarter. Data were then analyzed for each pathogen group, Table 1, as well as ignoring the pathogen classification, All Cases, Table 1, for each of five summary periods, Table 2 .

\section{STATISTICAL METHODS}

Animal rate, Quarter rate, Incident rate, Observation rate, and Average case duration were analyzed at each group classification, Table 1, for each of five summary periods, Table 2. Counts and proportions (Animal, Quarter, Observation, and Incident rates) were treated as discrete variables, and Average case duration was treated as a continuous variable.

For the count and proportion data, a generalized linear mixed model associated with each of the four response variables, Animal, Quarter, Observation and Incident rate, is given in Table 3. The analyses were conducted using the GLIMMIX macro, SAS V6.12. If the criterion for using a generalized linear mixed model was not met or if the model failed to converge, then an exact method, Proc StatXact ${ }^{\circledR}$ v4.0 (Mehta and Patel, 1987), was conducted. If the data were too 
sparse, for instance, when both parity groups had less than three observations, then a frequency table was created.

For the continuous response variable, Average case duration, a linear mixed model was used (Table 4). The analysis was conducted using Proc Mixed SAS V6.12.

\section{RESULTS}

Results will focus on two periods of the study, Calving 30-CD and 50-CE, Table 2, at All Cases level since $94.1 \%$ of the clinical mastitis incidents occurred during these two periods. Tables 5 and 6 show the etiology of mastitis cases by Monensin concentrations for each of the five variables Animal rate, Quarter rate, Observation rate, Incident rate and Average case duration during 30-CD and 50-CE, respectively.

For the 30-CD period, no Parity by Treatment interactions were detected $(\mathrm{P}>0.25)$ and no Monensin effects were detected $(\mathrm{P}>0.10)$ for Animal, Quarter, Observation, or Incident rates, as well as Average case duration (Table 5).

For the 50-CE period, Parity by Treatment interaction was detected $(\mathrm{P}=0.01)$ for Average case duration. Therefore, analyses for Average case duration were conducted for each parity. Observation rate for clinical mastitis was lower $(\mathrm{P}<0.10)$ in the $24 \mathrm{ppm}$ Monensin group than the controls (Table 6). However, there is no indication that Monensin should reduce Observation rate in dairy cattle. No other effects were detected $(\mathrm{P}>0.10)$ for either Animal, Quarter or Incident rate. For Average case duration, primiparous cattle receiving Monensin at $8 \mathrm{ppm}$ had a longer duration than controls ( $\mathrm{P}=0.01$, Table 6$)$. This was caused by one cow from the $8 \mathrm{ppm}$ group with a case duration 320 days.

\section{SUMMARY}

Monensin did not adversely affect the incidence or duration of clinical mastitis across etiologies, in either the first or second lactation of dairy cattle.

When clinical mastitis data were analyzed at All Cases level, some significant differences between non-zero concentration of Monensin and control were detected. No significant differences were detected for any rate or duration variable for the period 30-CD. A significant Observation rate reduction for the $24 \mathrm{ppm}$ Monensin group, and a significant longer Average case duration for the $8 \mathrm{ppm}$ Monensin group were detected when compared to control for the period, 50-CE. In general, no consistent patterns indicating that Monensin adversely affect the incidence of mastitis for any pathogen group were detected. 


\section{CONCLUSION}

We found no evidence to indicate that Monensin influences the susceptibility of dairy cattle to clinical mastitis.

\section{REFERENCES}

Mehta, C. and N. Patel. 1997. Proc-StatXact for SAS Users. CYTEL Software Corporation. Cambridge, MA.

Wolfinger R. and M. O’Connell. 1993. Generalized Linear Mixed Models: A PseudoLikelihood Approach. Journal of Statistical Computation and Simulation 48:233-242.

Littell, R., G. Milliken, W. Stroup and R. Wolfinger. 1996. SAS® System for Mixed Models. Cary, NC. 
Table 1. Group Codes for Microorganisms or Infection Type

\begin{tabular}{|c|c|c|}
\hline $\begin{array}{c}\text { Group } \\
\text { Description }\end{array}$ & $\begin{array}{l}\text { Microorganism } \\
\text { Code }\end{array}$ & $\begin{array}{l}\text { Microorganism or } \\
\text { Infection Type }\end{array}$ \\
\hline All Cases & ALL & All clinical mastitis cases regardless of culture results \\
\hline Contagious Pathogen (CP) & $\begin{array}{l}01 \\
03 \\
08 \\
14\end{array}$ & $\begin{array}{l}\text { Staphylococcus aureus } \\
\text { Streptococcus agalactiae } \\
\text { Corynebacterium bovis } \\
\text { Mycoplasma spp. }\end{array}$ \\
\hline $\begin{array}{l}\text { Environmental Pathogen } \\
\text { (EP) }\end{array}$ & $\begin{array}{l}04 \\
05 \\
06 \\
07 \\
11 \\
12\end{array}$ & $\begin{array}{l}\text { Streptococcus dysgalactiae } \\
\text { Streptococcus spp. } \\
\text { Escherichia coli, Enterobacter spp. } \\
\text { Other Gram-Negatives } \\
\text { Streptococcus uberis } \\
\text { Klebsiella spp. }\end{array}$ \\
\hline $\begin{array}{l}\text { Staphylococcus spp., } \\
\text { coagulase-negative } \\
\text { staphylococci (CNS) (SP) }\end{array}$ & 02 & Staphylococcus spp. \\
\hline $\begin{array}{l}\text { Other Microorganisms } \\
\text { (OT) }\end{array}$ & $\begin{array}{l}09 \\
13 \\
15 \\
16 \\
17 \\
50\end{array}$ & $\begin{array}{l}\text { Other Microorganisms } \\
\text { Coagulase-positive Staphylococcus } \\
\text { hyicus } \\
\text { Nocardia spp. } \\
\text { Actinomyces pyogenes } \\
\text { Pseudomonas spp. } \\
\text { Mixed infection } \\
\text { These are microorganisms not } \\
\text { included in EP, SP, CP, or negative. }\end{array}$ \\
\hline $\begin{array}{l}\text { Undetermined Etiology } \\
\text { (UE) }\end{array}$ & $\begin{array}{c}\text { MS } \\
10 \\
\text { UD } \\
00\end{array}$ & $\begin{array}{l}\text { Missing samples } \\
\text { Contaminated samples } \\
\text { Undetermined samples } \\
\text { Samples where results were classified } \\
\text { as negative }\end{array}$ \\
\hline
\end{tabular}

Table 2. List of Five Summary Periods for Clinical Mastitis Cases

\begin{tabular}{cl}
\hline Period & \multicolumn{1}{c}{ Description } \\
\hline 05-TC & Treatment start to Calving 1 \\
30-CD & Calving 1 to Dry-Off \\
35-DC & Dry-off to Calving 2 \\
45-C7 & Calving 2 to 7 DIM \\
50-CE & Calving 2 to 203 DIM \\
\hline
\end{tabular}

DIM: Days in milk 
Table 3. Generalized Linear Mixed Model for Animal, Quarter, Observation, and Incident Rate

\begin{tabular}{|c|c|c|c|c|c|}
\hline & \multicolumn{5}{|c|}{$\begin{array}{l}\eta_{\text {ghij }}=E\left(O_{\text {ghij }} \mid \gamma_{\mathrm{h}}, \gamma \tau_{\mathrm{hj}} \text {, and } \gamma \beta_{\text {ghi }}\right) \text { offset by } \log _{\mathrm{e}}\left(\mathrm{R}_{\mathrm{ghij}}\right) \text { for Observation rate, } \\
\eta_{\text {ghij }}=\mathrm{E}\left(\mathrm{C}_{\mathrm{ghij}} / \mathrm{R}_{\mathrm{ghij}} \mid \gamma_{\mathrm{h}}, \gamma \tau_{\mathrm{hj}} \text {, and } \gamma \beta_{\mathrm{ghi}}\right) \text { for Incident rate, } \\
\mathrm{g}(\bullet)=\text { link function (logit or loge }) \text { used to linearize conditional mean for GLIMM. } \\
\text { and }\end{array}$} \\
\hline$\mu$ & Common mean & $\gamma_{\mathrm{h}}$ & Trial site effect & ه & Indicates parity \\
\hline$P_{g}$ & Parity effect & $\gamma \tau_{\mathrm{hj}}$ & $\begin{array}{l}\text { Trial by treatment } \\
\text { interaction }\end{array}$ & h & Indicates the $h^{\text {th }}$ trial site \\
\hline$\tau_{\mathrm{j}}$ & Treatment effect & $\gamma \beta_{\text {ghi }}$ & $\begin{array}{l}\text { Block within trial site } \\
\text { effect }\end{array}$ & i & Indicates the $\mathrm{i}^{\text {th }}$ block \\
\hline$P \tau_{g j}$ & $\begin{array}{l}\text { Parity by treatment } \\
\text { interaction }\end{array}$ & & & & $\begin{array}{l}\text { Indicates the } \mathrm{j}^{\text {th }} \text { treatment } \\
\text { group }\end{array}$ \\
\hline
\end{tabular}

Table 4. Linear Mixed Model for Average Case Duration

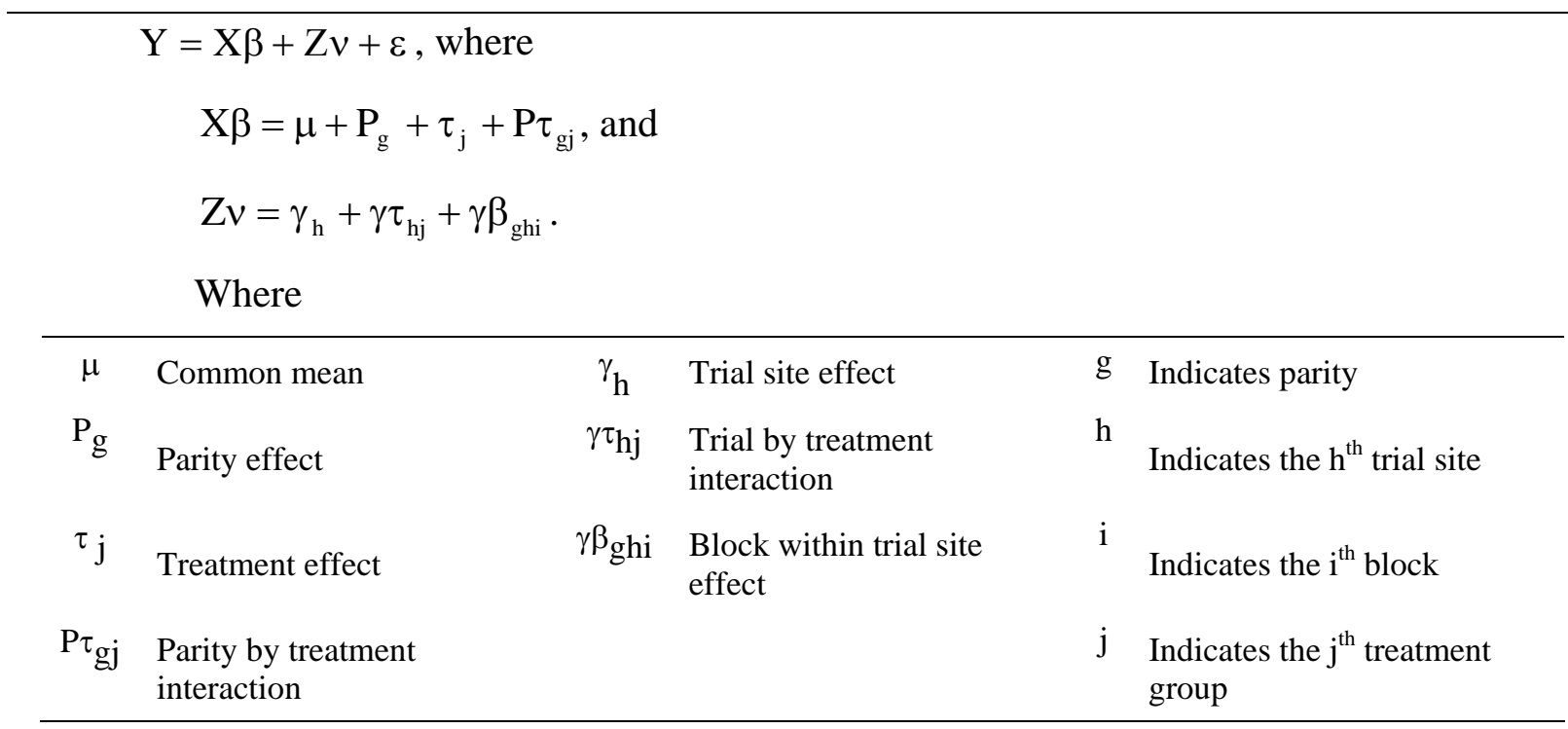


Table 5. Summary of Clinical Mastitis Incidents (All Cases) in the Calving 1 to Dry-Off Period Across All Sites.

\begin{tabular}{|c|c|c|c|c|}
\hline \multirow[b]{2}{*}{ Variables } & \multicolumn{4}{|c|}{ Monensin Concentration (ppm) } \\
\hline & 0 & 8 & 16 & 24 \\
\hline Animal rate & 0.472 & 0.451 & 0.405 & 0.428 \\
\hline Quarter rate & 0.200 & 0.197 & 0.175 & 0.185 \\
\hline $\begin{array}{l}\text { Observation rate (per } 1000 \text { quarter } \\
\text { days at risk) }\end{array}$ & 4.375 & 5.164 & 4.665 & 5.011 \\
\hline $\begin{array}{l}\text { Incident rate (per } 1000 \text { quarter } \\
\text { days at risk) }\end{array}$ & 0.893 & 0.865 & 0.749 & 0.764 \\
\hline Average case duration (days ) & 7.34 & 8.82 & 7.48 & 8.12 \\
\hline
\end{tabular}

Note: Monensin non -zero concentration means were not different from controls.

Table 6. Summary of Clinical Mastitis Incidents (All Cases) in the Calving 2 to 203 DIM Period Across All Sites

\begin{tabular}{lrrrr}
\hline & \multicolumn{5}{c}{ Monensin Concentration (ppm) } \\
\hline \multicolumn{1}{c}{ Variables } & 0 & \multicolumn{1}{c}{8} & \multicolumn{1}{c}{16} & \multicolumn{1}{c}{24} \\
\hline Animal rate & 0.589 & 0.521 & 0.490 & 0.478 \\
Quarter rate & 0.279 & 0.239 & 0.213 & 0.200 \\
$\begin{array}{l}\text { Observation rate (per 1000 days at } \\
\text { risk) }\end{array}$ & 13.570 & 15.713 & 13.317 & $7.804^{*}$ \\
$\begin{array}{l}\text { Incident rate (per 1000 days at risk) } \\
\text { Average case duration, days - }\end{array}$ & 1.90 & 1.716 & 1.907 & 1.511 \\
$\begin{array}{l}\text { Multiparous } \\
\text { Average case duration, days - }\end{array}$ & 14.12 & 8.5 & 10.06 & 10.93 \\
Primiparous & 16.78 & $34.54^{*}$ & 14.36 & 9.95 \\
* Statistically significant pairwise comparison versus control (P<0.100). & & & \\
\hline
\end{tabular}

